Special Issue 特集論文

Invited Peer-Reviewed Article 招待査読論文

\title{
Interactive Evolution of Marketing Functions between Platforms and Individual Business Operators マーケティング機能をめぐるプラットフォームと 個別事業者の相互作用的進化
}

\begin{abstract}
Tatsuyuki Negoro*1, Satoshi Ajiro*2
早稲田大学大学院 経営管理研究科

根来 龍之

拓殖大学 商学部

足代 訓史

${ }^{* 1}$ Graduate School of Business and Finance, Waseda University, Japan, negoro@waseda.jp

${ }^{* 2}$ Faculty of Commerce, Takushoku University, Japan, sajiro@st.takushoku-u.ac.jp

Abstract : This paper discusses the interactive evolution of marketing functions between platforms (PFs) and individual business operators. The purpose is to present a new model and hypotheses that differ from the "PF-centered view of the relationship between a PF and its complements," upon which existing interaction-type platform studies basically rely. For this purpose, the paper conducts a case study of interactive development of customer-interaction functions between PFs and individual business operators in the restaurant chain industry. As a result of the case study, we argue the following propositions: marketing functions of interaction-type PFs and individual business operators develop through interactive competition for functional expansion; and individual business operators may collaboratively develop PF functions to take advantage of the network effects of the PF.
\end{abstract}

Keyword : Interaction-type platform, Complementor (Individual business operator), Marketing function, Interactive evolution, Restaurant chain industry

要約：本稿は，マーケティング機能を対象に，媒介型プラットフォーム（Platform: PF）における PF と補完者（個別事業者） との関係の相互作用的進化について論じる。その目的は, 既存の PF 研究が基本的に依拠する,「PF を中心に据えて, PF とそ の補完者との間の関係を論じる見方」とは異なる関係モデルと一般化仮説を提示することである。そのために本稿では, 飲食店 チェーン業界において，PF と個別事業者との間で, 顧客接点機能を相互発展させている現象を事例分析する。事例研究の結果 として, 以下の命題を主張する。媒介型 PF と個別事業者のマーケティング機能は, 相互的機能拡張競争によって発展する。ま た，個別事業者は媒介型PF のネットワーク効果を活用するために，協業的にPF 機能の開発を行うことがある。

キーワード : 媒介型プラットフォーム, 補完者 (個別事業者)，マーケティング機能，相互作用的進化，飲食店チェーン業界

Information : Received 31 May 2021; Accepted 6 June 2021

\section{I. 本稿の問題意識}

本稿が議論の対象とするプラットフォーム (Platform : 以下，PF と表記することがある）には大きく分けて， $\mathrm{PF}$ 技術・部品と PF 製品・サービスとが存在する (Negoro \& Ajiro, 2013)。PF 技術・部品とは, 例えば通信技術の ような企業間・製品間をまたがる基盤技術，あるいは自 動車のシャーシのような製品開発上の基盤部品など，多
様な製品開発に用いられるコア技術・部品を指す。一方, $\mathrm{PF}$ 製品・サービスとは, 「他のプレイヤー（企業，消費 者など）が提供する製品・サービス・情報と一体になっ て, 初めて価值を持つ製品・サービス」(Negoro, 2017, p. 17）のことである。ここで，この「他プレイヤー」の ことを，「補完者」と呼び，それらが提供する製品・サー ビスを「補完品」と呼ぶ。

$\mathrm{PF}$ 製品・サービスには, 顧客の求める製品・サービス の基盤となる $\mathrm{PF}$ と, コミュニケーションや取引の媒介 
となる PF の二種類が存在する (Cusumano, Gawer, \& Yoffie, 2019; Negoro, 2017)。前者は例えば，スマートフォ ン（以下では，スマホと表記）の OS, ゲームのハード のように, 補完品（OSにとってのアプリ, ゲームハー ドにとってのソフトなど）と合わさって顧客の求める機 能を実現する製品・サービスの基盤となるものを指す。 後者は例えば，ユーザー間のコミュニケーションの場と なる SNS や, 決済・取引の媒介機能を持つ電子マネーの ような製品・サービスを指す。

本稿が対象とするのは，後者の媒介型 PF である。さ らに，媒介型 PFには，「ネット以前には存在していな かったサービス」と，「〈ネット以前から存在していた個 別事業者のビジネス機能〉の一部を分離して，企業をま たがって横断的に提供するサービス」として誕生・発展 しているものがある。例えば，ネットオークションは前 者の例であり（ネット以前のオークションは主に美術・ 骨董品を対象とした別市場），PF のクーポンビジネスは 後者の例である（ネット以前にも，例えば飲食店は紙や カード式のクーポンを発行していた)。本稿は，媒介型 $\mathrm{PF}$ の中でもさらに後者の「個別事業者のビジネス機能の 一部」を提供する PF と, そのビジネスの対象となる個 別事業者（Individual Business Operator：以下，IO と表 記することがある）との関係を対象にするものである。 本稿は, PFが，もともと個別事業者が持っている機能を 取り込み共通化することで誕生・発展する過程から始ま るプロセスを対象にするため, PF 独自の市場創造から始 まる前者は対象とならない。

本稿の問題意識は, 上記を対象に, 従来の「プラット フォームを中心に据えて, プラットフォームとその補完 者との間の関係を論じる見方」を補う,「プラットフォー 厶 $(\mathrm{PF})$ と個別事業者 (IO) との間で起こる相互作用的 進化の見方」を示すことである。その問題意識を追求す るプロセスとして本稿では, マーケティング機能に着目 して，後者の見方に立つモデルと一般化仮説を提示する ことを目的とする。

そのために, 本稿では, まず PF が, IO が本来有して いたどのマーケティング機能を取り込むことで PF とし て誕生するかという点から分析を始める。そのうえで, PF と IO が相互に参照しあうことで, 各々が自社の提供
機能を発展させていくメカニズムに着目する。具体的事 例として, 飲食店チェーン業界（以下, 飲食店業界と表 記）における PF と IO との間の機能拡張競争の分析か ら,「PFと IO の相互作用的進化のモデル」を提案する。 本稿は, 一般化の範囲として上述の通り,「ネット以前 から存在していたIO のビジネスの機能を分離して, PF が各企業をまたがって横断的にサービスを提供する」業 界一般を想定している。ただし，本稿で実際に分析する のは, 飲食店業界に押いて PFが提供している製品・サー ビス, 具体的にはクーポンやポイント, デリバリーなど, 元々はIO が独自に提供していた, 企業とエンドユーザー との間のコミュニケーションや取引に関連するもの, つ まり顧客接点に関連するマーケティング機能である。な お, 本稿が提案する見方では補完者という言葉は適切で ないので, 本稿では適宜「個別事業者 (IO)」という言 葉を用いる。ただし，IO が PF を利用する場合には，PF の補完者となる。

\section{II. 先行研究の検討と本稿のリサーチクエスチョン}

以下では，本稿の対象である媒介型 PF に関する主な 先行研究を検討する。それによって, 上述した「PFと IO との間で起こる相互作用的進化の見方」が, 既存研究 が暗黙に依拠する立場とどう異なるかを示す。その上で, 本稿のリサーチクエスチョン（RQ）を提示する。

\section{PF 視点の研究}

PF に関しては, ッーサイド PF（Two-Sided PF）に着 目した研究が進展している (Eisenmann, Parker, \& Van Alstyne, 2006, 2011; Hagiu \& Yoffie, 2009; Parker, Van Alstyne, \& Choudary, 2016)。これらの研究では, PF は $\lceil$ Products and services that bring together groups of users in two-sided networks（二つのユーザーグループを結びつ け, ッーサイドのネットワークを創発する製品やサービ ス)」(Eisenmann et al., 2006, p. 94）と，PF の持つ媒介 性を意識して定義されるのが通常である。

媒介型 PF のマネジメントに押いて重要となるのが, ユーザーグループ（サイド）間に発生するネットワーク 
効果の存在である (Armstrong, 2006; Eisenmann et al., 2006)。媒介型 PF におけるネットワーク効果には，「サ イド間ネットワーク効果」と「サイド内ネットワーク効 果」が存在する。前者は，片方のサイドのユーザーが増 加すると，もう片方のサイドにとって PF の価值が向上 あるいは低下する現象を指す。サイド間ネットワーク効 果は，消費者と補完者という異なるユーザーグループの 間に働くものである。一方，後者のサイド内ネットワー ク効果は，ユーザーの数が増えると，そのユーザーが属 するグループにとって，PF の価值が向上あるいは低下す る現象を指す。

これらのネットワーク効果をマネジメントすることが, 媒介型 PF の価值向上，ひいては特定の PF が一人勝ちに 至る要因の一つとなることがこれまで指摘されてきた (Cusumano et al., 2019; Eisenmann et al., 2006; Negoro, 2017）。そのため PF は，消費者や補完者を自社 PF へと 参加させるために, 特定のユーザーグループに対してコ スト割れの価格設定を設定したり，PF 上に魅力のあるス ター製品を用意したり（Eisenmann et al., 2006, 2011）, 時にはユーザーに対する優先順位付けを行ったりする (Moazed \& Johnson, 2016)。とりわけ，サイド間ネット ワーク効果を高めるために，ユーザーに訴求できる補完 者を PF に参加させることは，PFにとって必須となる。 そのため, PF は API のオープン化を行ったり，参加の ための障壁を下げたり（例：開発費用の補助）すること で補完者が参加しやすくしたり（Boudreau, 2010), 補完 者によるイノベーションの誘因となるッールの提供を 行ったりする (Gawer, 2009)。このように，既存研究で は，PFが補完者を含むエコシステムをどう拡大していく かが重要な議論となってきた (Cennamo \& Santalo, 2013)。

\section{2. 補完者視点の研究}

他方，一般に PF の立場で議論を行うことが多い PF 研 究の中で, 補完者の観点から研究を行ってきた文献も存 在する。補完者（個別事業者（IO））にとって，どの PF に参加するかは，自社の収益を左右する問題である (Ceccagnoli, Forman, Huang, \& Wu, 2012)。例えば, Hagiu and Yoffie（2009）は，補完者が PF への参加の際に留意 すべき要諦として，（1）既存の PF を利用すべきか,
どの PF に参加すべきか，（3）どのように PF を利用すべ きか，の三点を提示する。

また, 先行研究の中には, 補完者の PF への依存を減 らすための戦略を整理するものもある。Edelman（2014） は, 補完者と媒介型 PF との関係に着目することで, PF が網羅できないサービス・機能領域に補完者がつけ込む ことや，PFを介さない直接取引を強化することを，補完 者が取り得る戦略として提案している。また，PFがその 支配力を前提とした優越的な行動を取ることの是非を世 に訴えることや，他の PF を支援・設立することも，補 完者の戦略オプションとしてあげている。

しかし，こうした補完者視点での先行研究はあくまで も, PFによる補完者の勧誘や管理に対して, 補完者がど のように対抗 (対応) するかという，PF 側からのコント ロールが存在することを前提とした研究となっている。 ただし，Amazonの電子書籍のPFである Kindle に対し て，海外旅行用ガイドブックを出版している個別プレイ ヤー（補完者）がどのように出版の意思決定を行ってい るか，いかにして PF の関与の範囲を限定して自社の交 渉力を保っているかを論じた Wang and Miller（2020）の 研究には, 出版社の PF に依存しない出版活動を PF から 独立した活動として明確に研究対象にしているという意 味で，本稿の問題意識に通じる視点の萌芽がある。

\section{3. 既存研究における死角}

以上で見た先行研究は，PF を中心に据えたうえで，い かにしてエンドユーザーや補完者を针誘，管理するかと いう観点に立ったものであったといえる。また, 補完者 視点の研究も, 強力な交渉力を持った $\mathrm{PF}$ を中に据え たうえで，補完者がいかにしてそこに参加するか，利用 するかといった観点に立ったものであったといえる。既 存研究での「補完者」という表現自身がその問題意識の 反映である。これが, 本稿が, 既存研究は PF 視点であっ ても，補完者視点であっても，「PFを中心に据えたモデ ル」を前提にすると規定する理由である。実際，当該分 野の既存研究を網羅的にレビューした McIntyre and Srinivasan（2017）では, PF 研究の対象は「PF 仲介ネッ トワーク (Platform-Mediated Networks)」であるとして, 研 究の前提として常にツーサイド PF 論が意識されている。 
しかし，そもそも上述した本稿の対象においては，事 業者が PF に頼る活動は一部だけである。さらに，ある 業界において媒介型 PF が発達した後でも，PF の機能を 自社に取り込もうとする事業者も存在する。また，媒介 型 PF を利用しない事業者も存在する。したがって，本 稿もッーサイド PF 論が中心的対象とする媒介型 PF を一 方の対象とするものではあるが，本稿の立場では，事業 者はPF の存在を前提にしてそれを「補完」する存在で はなく,「独立の事業者（個別事業者：IO）」なのであ る。この場合 IO は，時と場合に応じて媒介型 PF を利用 すること「も」あると考えることができる。本稿の議論 は，このような見方を前提に，PFによる「補完者」の勧 誘・管理，あるいは補完者の $\mathrm{PF}$ の参加ではなく, PF と IO を対等の当事者として設定して両者の相互作用を 対象とする。

詳細は後述するが, 本稿が分析対象とする飲食店業界 においては, PF の機能には, 元々 IO が行っていた活動 をIO を横断する形で提供しているものが多い。クーポ ンやポイント，デリバリーがその例である。ただし，PF は, IO が元来保有していた機能を単に取り込んで共通化 するだけでなく，それを発展させる。例えば，「IO をま たがる購買行動」の分析は PF 特有の提供機能である。 一方で, IO も単に PFに依存するのではなく，例えば Web やスマホによるオーダー機能を自社提供すること で, PF から顧客接点を取り戻したり，機能毎に PF を利 用したり利用しなかったりする。

本稿では，媒介型 PF である LINE や PayPay などと， IO である飲食店とが相互にその行動を参照しあうこと で，互いに参照相手の提供サービス・機能を取り込み， それらを改善・強化し合う現象を分析する。なおここ で「参照」とは，PF と IO の間で行われる経営行動の観 察や確認という意味である。PF が参照するのは，潜在的 利用企業も含めた IO「群」であるが，IO が参照するの は具体的な個別の PFである。こうした現象の分析を通 じて，「PFを中心に据えた補完者の管理と補完者側から の対応」という既存研究のパースペクティブではなく, 「PF と IO を対等の当事者として設定して，両者の間で 起こる相互作用的進化」として見る新しいパースペクティ ブとその意義を示すことができると考えている1)。

\section{4. 調査の方法とリサーチクエスチョン}

本稿では研究方法として単一事例研究を採用する (Yin, 1994）。本稿の目的は, PF と IO との間で起こるマーケ ティング機能の相互作用的進化のメカニズムに関するモ デルと一般化仮説を提示することにある。そのメカニズ ムは, 飲食店業界に执いて確認できる現象を時系列に沿っ て分析することで提示される。従って，現実の文脈にお ける現在に至るプロセスに分析の焦点があり，観察者が 事象をほとんど統制できない問題を，時間軸をもとに丹 念に検討する際に効果的である単一事例研究のアプロー チを選択し（Eisenhardt, 1989），仮説を導出することを 目的として理論産出型事例研究を行う（Shibuya, 2009）。

本稿が分析対象とする事例は, 飲食店業界における PF と IO との間で起こるマーケティング機能の機能拡張競 争である。当該業界を分析対象とするのは, 業界内のバ リューチェーンに扔いて，PF と IO との間で顧客接点の 奪い合いが時系列で確認されるからである。本稿では具 体的には, クーポン (集客), オーダー, 決済, ポイン ト，デリバリーの五つのマーケティング機能を取り上げ て業界全体の動向をまず概観的に分析する。次に，この 業界で PF と IO との相互作用が確認できる典型的事例と して, 媒介型 PF である LINE と IO であるコーヒーチェー ンのスターバックスジャパン（以下では，スタバと表記 することがある）との機能拡張競争の事例を詳細に分析 する。なお本稿では, 機能拡張競争の結果, PF と IO の 顧客接点機能の相互作用的進化が進むと考えるが, ここ で「進化」という概念は経路依存的な発展を意味する。

本稿が分析対象とするサービス・機能を，マーケティ ング機能に限定している理由を説明しておきたい。飲食 店業界に扔いて媒介型 PF が提供しているサービス・機 能はマーケティング機能だけとは限らない。例えば，資 材調達機能や求人機能に関する媒介型 PF も存在する。 これらの機能に関しても PF と IO の間で機能拡張競争が ありえるが, 現時点ではマーケティング機能ほど顕著で はない。言い換えると, 現時点ではマーケティング機能 に扔いてより強い機能拡張競争が観察される。その理由 は, 以下だと考元られる。まず, 当該業界においてマー ケティング機能に関する IO の PFへの依存度が高まり， 飲食店の顧客接点を $\mathrm{PF}$ に奪われてしまうと, IO の顧客 
に対するコミュニケーション力は確実に弱まる。自社で 顧客デー夕を収集できれば, PF に依存せずに One to One マーケティングを実行できる（逆に One to One マーケ ティングを志向しない会社は自社での顧客デー夕収集を 必ずしも重視しないので, PF 依存をより選択する傾向が ある)

なお， マーケテイング機能に製品開発や店舗展開など も入れることがあるが，本稿が分析するマーケティング 機能は，顧客接点に関係する「潜在顧客へのリーチ拡大， 新規顧客獲得，顧客維持率向上，利用頻度向上，顧客単 価向上に関連する提供機能」のことである（広義の CRM (Customer Relationship Management）機能)。そこで，以 下では，顧客接点機能という言葉も使うことにする。

事例研究は，主に対象事例に関する一次・二次資料の 詳細な分析とインタビュー調查を通じて行った。具体的 には，分析対象の施策や経営行動に関して，対象各社の Web サイトやプレスリリース，関連記事に掲載されてい る内容をもとに分析を行った。また，一部の分析対象企 業について，インタビュー2)あるいは公開講演会で入手 した情報に基づき，公開資料から得た情報の事実確認も 行い，分析内容の信頼性の確保に努めた。

ここまでの検討を踏まえ，本稿のリサーチクエスチョ ン（RQ）を以下の通り設定する。

$\mathrm{RQ}$ ：媒介型プラットフォームと個別事業者のマーケティ ング機能（顧客接点機能）の相互作用的進化の具体 的内容とそのメカニズムはどのようなものか

\section{III. 事例分析}

\section{1. 飲食店業界における顧客接点機能拡張競争のマクロ 的分析}

以下ではまず, 飲食店業界の顧客接点機能をめぐる $\mathrm{PF}$ と IO との機能拡張競争の状況をマク口的に分析する。 ここで分析の対象となる $\mathrm{PF}$ は, 飲食店業界に関する顧 客接点機能, すなわち集客 (クーポン) やオーダー, デ リバリーなどの機能を提供している PFである。なお， この種の PF は業界をまたがったサービスを行っている ことが多い。

（1）バリューチェーンにおける媒介型 PF の影響力の拡大 近年, 飲食店業界においては顧客の維持・獲得, 生産 性の向上を目的とした，顧客接点機能のデジタル化が進 んでいる。デジタル化は IT や Web 技術などを基盤とし て進行し，当該技術を用いた製品・サービスに強みを持 つ媒介型 PF の活動範囲が飲食店業界でも拡大している。 具体的には, 飲食店業界のバリューチェーンに扔ける顧 客接点関連の各プロセスでの媒介型 PF の活動状況は図 1 のように整理できる。例えば，オーダーの箇所では O:der（オーダー：(株) Showcase Gig）のようなスマホ 注文に特化した PF に加え, LINE のような総合型の PF がテイクアウト用オーダー機能を提供している（本稿執 筆時点では LINE 傘下の出前館が提供)。

（2）顧客接点機能をめぐる機能拡張競争

媒介型 PF が業界での影響力を拡大している一方で,

図 1 飲食店業界における顧客接点機能関連の主要な媒介型プラットフォーム

\begin{tabular}{|c|c|c|c|c|c|}
\hline $\begin{array}{c}\text { バリューチェーン } \\
\text { のプロセス }\end{array}$ & 集客 & オーダー & 決済 & ポイント & デリバリー \\
\hline $\begin{array}{l}\text { 主要な媒介型PF } \\
\text { (サービス名) }\end{array}$ & $\begin{array}{l}\cdot \text { LINEクーポン } \\
\cdot \text { SmartNews } \\
\cdot \text { Gunosy } \\
\cdot \text { ホットペッパー } \\
\text { グルメ } \\
\cdot \text { 食ベログ }\end{array}$ & $\begin{array}{l}\cdot \text { ポケオ } \\
\cdot \text { O:der } \\
\cdot \text { PICKS }\end{array}$ & $\begin{array}{l}\cdot \text { PayPay } \\
\cdot \text { LINE Pay } \\
\cdot \text { 楽天Pay } \\
\cdot \text { メルペイ } \\
\cdot \text { d払い } \\
\cdot \text { iD }\end{array}$ & $\begin{array}{l}\cdot \text { 楽天ポイント } \\
\cdot \text { dポイント } \\
\cdot \text {-T-POINT } \\
\cdot \text { Ponta }\end{array}$ & $\begin{array}{l}\cdot \text { Uber Eats } \\
\cdot \text { 出前館 } \\
\cdot \text { LINEデリマ } \\
\cdot \text { 楽天デリバリー } \\
\cdot \text { menu }\end{array}$ \\
\hline
\end{tabular}

出典：筆者作成。 
その補完者となる飲食店（個別事業者 (IO) ) も一方的 に PFへの依存度を高めていたり，PFの利用という観点 のみによって行動していたりするわけではない。実際， 少し時系列を長くとって, バリューチェーンの各プロセ スを観察してみると，PF と IO が相互に顧客接点機能の 提供や改善を繰り返す機能拡張競争が観察できる。

一例を挙げると，飲食店業界における集客機能に関し ては，もともとはIO 自身によって紙でのクーポン（割 引券）が提供されていた。例えば, マクドナルドにおい ては，デジタル化が進行するよりも遙か前から，チラシ や店頭で提供される商品への添付でクーポンが配布され ていた。その後, 2010 年 12 月にスマホ用マクドナルド 公式アプリの提供が開始されると ${ }^{3)}$ ，それを用いたデジ タルクーポンの利用が普及していった。後述するが，ス タバも 2013 年の 6 月から,「Starbucks eTicket」という 自社独自クーポン(商品との交換券)の提供を行っている。

このように旧来から存在していたクーポンをビジネス 化したのが，媒介型 PF のクーポンサービスである。 2012 年 8 月に LINE は，飲食店各社のクーポンを集めて消費 者に提示する「LINE クーポン」の提供を日本国内で開 始した ${ }^{4)}$ 。また, 2018 年 3 月にスマートニュースが開始 した「スマートニュースクーポンチャンネル」は，その 1 年強後には累計 20 億回ページビューを記録するサービ スへと成長した 5)。さらに LINE では, 2019 年 4 月より 事業者向けの LINE@アカウントを LINE 公式アカウント （企業と顧客が LINE を使ってダイレクトにコミュニケー ションできる媒介型サービス）へと刷新し，それを用い た飲食店のクーポン配布ができるようにした。IOである マクドナルドやスタバも, 販売機会拡大を目的として, これら PF に補完者として選択的に参加し，クーポンを 配布している。

もっとも，媒介型 $\mathrm{PF}$ へ過度の依存は，顧客接点を PF に奪われたり，コスト的に見合わなかったりするとい う判断から，IO はPF に依存しない集客も行う。実際日 本マクドナルドは 2015 年 4 月にマクドナルド公式アプ リを刷新し，紙のクーポンをやめてバーチャルクーポン の提供を開始した 6)。マクドナルドの場合は, PF のクー ポンサービスにも積極的に参加している。これは同社が マスマーケティングを志向しているので, PF 活用を主に
コストパフォーマンスで判断しているからだと考えられ る7)。スタバの場合は, One to One マーケティング志向 があり,より積極的に自社アプリの機能拡張を続けて いる。

このように部分的に PF と補完者という関係を維持し つつも，それぞれが別々に顧客接点機能を発展させてい る取り組みが, 飲食店業界における集客（クーポン）機 能以外の顧客接点機能においても確認できる（表 1)。次 節では, このような現象の中から, IO であるスタバと媒 介型PFである LINE の機能拡張競争の事例を詳細に分 析する。なお，ここで「競争」とは，当事者に競争して いる意識があるかどうかとは関係なく, 現象として観察 できる相互作用を指している。

\section{2. スターバックスと LINE の機能拡張競争}

(1) スターバックスの顧客接点強化の取り組み

まず，スタバの顧客接点機能に関する取り組み状況に ついて概観しておく。これまで同社は一貫して, 顧客接 点のデジタル化に力を入れてきた。日本国内では，2002 年 10 月に公式 Web サイトや自社発行の IC カードである 「スターバックスカード」(プリペイドカード）を導入し た。その後 2013 年にはオンラインストアを開設し, 店 舖で商品と交換可能な電子チケットの「Starbucks eTicket」の提供を開始した (2013 年 6 月)。2014 年 2 月 には，モバイル決済を可能とする「モバイルスターバッ クスカード」を導入，さらに 2016 年 5 月に公式モバイ ルアプリを導入した ${ }^{8)}$ 。

また，同社では，2017 年の 9 月に顧客の体験価值を向 上させるための取り組みであるロイヤルティプログラム である「Starbucks Rewards」を導入した。これにより， 顧客は自社サイトや公式アプリに登録したスターバック スカードで商品を購入することで,「Star（スター）」と いうポイントを䝪めたり, 新商品の先行購入や限定イベ ントへの招待を受けたりすることができるようになった99。 他にも，近年スタバは事前オーダーサービスの拡充に 力を入れている。同社では事前に公式モバイルアプリで 注文した商品を，店舗でレジに並ばずに受け取ることが できる「Mobile Order \& Pay」サービスを提供している (国内は 2019 年 6 月から)。そこでは, 商品の注文以外 

マーケティング機能（顧客接点機能）をめぐる個別事業者と媒介型 PF の機能拡張の例

\begin{tabular}{|c|c|c|}
\hline プロセス & 個別事業者の機能拡張の例 & 媒介型 PF の機能拡張の例 \\
\hline 集客 & $\begin{array}{l}\text { ・日本マクドナルドの紙クーポン（旧来） } \\
\text { ・日本マクドナルド公式アプリでのクーポン（2010.12） } \\
\text { · Starbucks eTicket（2013.6） } \\
\text { ・日本マクドナルド公式アプリ（2015.4） } \\
\text { ・日本マクドナルド「KODO アプリ」(同上） }\end{array}$ & $\begin{array}{l}\text { · LINE クーポン (2012.8) } \\
\\
\text { · スマートニュースクーポンチャネル (2018.3) } \\
\cdot \text { Yahoo! Japan のアプリ内クーポンタブ }(2019.4) \\
\cdot \text { LINE 公式アカウントのクーポン }(2019.4)\end{array}$ \\
\hline オーダー & $\begin{array}{l}\text { •店頭や電話での直接受け付け（旧来） } \\
\text { ・自社サイト, アプリでのモバイルオーダー (マクドナルド, すき家等 }) \\
\text { •スターバックス「Mobile Order \& Pay」(2019.6) }\end{array}$ & 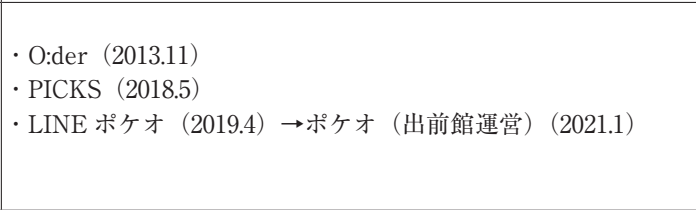 \\
\hline 決済 & $\begin{array}{l}\text { ·現金決済（旧来） } \\
\text { ・スターバックスカード（ICカード）（2002.10） } \\
\text { •モバイルスターバックスカード（モバイル決済可能）（2014.2） } \\
\text { ·自社アプリでの店頭での決済（いきなり！ステーキなど） }\end{array}$ & 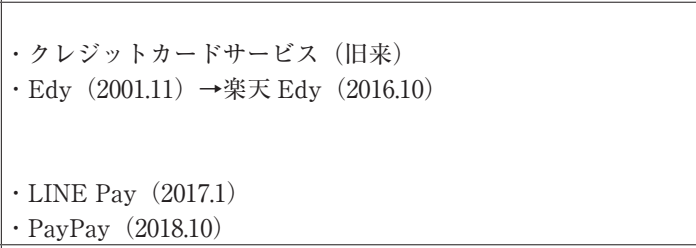 \\
\hline ポイント & $\begin{array}{l}\text { ・スタンプカード（旧来） } \\
\text { ・スターバックス公式モバイルアプリ（2016.5） } \\
\text { · Starbucks Rewards（2017.9） }\end{array}$ & $\begin{array}{l}\text { ・ツタヤポイントの共通ポイント化（T-POINT）（2003.10） } \\
\text { ・LINE スターバックスカード, LINE 公式アカウント (2019.4) }\end{array}$ \\
\hline デリバリー & $\begin{array}{l}\text { ・各店舗による出前サービス（旧来） } \\
\text { ・日本マクドナルド「マックデリバリー」(2012.11） }\end{array}$ & $\begin{array}{l}\text { ・出前館（2000.10） } \\
\text { • 楽天デリバリー (2002.2) } \\
\text { • Uber Eats }(2016.9) \\
\cdot \text { LINEデリマ }(2017.7)\end{array}$ \\
\hline
\end{tabular}

出典：筆者作成。

にカスタマイズや決済など，受け取り以外のプロセスが オンラインで完了できる。

こうした顧客接点の機能強化にIO として注力するス タバであるが，その一方で日本では媒介型 PFにも参加 することで顧客接点機能を強化している。次項において は, IO としてのスタバの取り組みと, 同社が補完者とし て参加する LINEの取り組みとの相互作用的発展を事例 分析する。

（2）顧客接点機能をめぐるスターバックスと LINE との 取り組み

スタバは自社で顧客接点の強化に取り組む一方, PF で ある LINEへの参加と同社との協業も行っている。両者
は 2015 年 4 月から LINE の「友だち」にギフトをプレゼ ントできる「LINE ギフト」サービスを実施したり，期 間限定の公式 LINE アカウントを設置したりすることで, 本格的な協業を模索してきた 10)。その動きが先鋭化した のが，2018 年 12 月に両者の間で締結された包括的業務 提携である。スタバでは元々，自社独自のサービスだけ で運用していくことに固執するのではなく, 個別に PF の活用を検討していた。他にも存在する複数 PF の中で LINE の活用にスタバが注力することにしたのは，LINE の持つリーチの広さを活用できることと, LINE の持つ メッセージ機能が,「人と人との繋がり」を重視するス夕 バの基本的方針と合致したからである11)。また，ス夕バ のブランドイメージを保持することと, 消費者と狙い通 
りのコミュニケーションを取るためにチャネルを限定す るという意図もあった ${ }^{12)}$ 。

2019 年 4 月には, (1) LINE 上で発行される「LINE ス ターバックスカード」の開始，（2）スタバの LINE 公式 アカウントの開設とそれを用いた消費者との One to One コミュニケーションの実現，（3）LINE Pay（2017 年 1 月 開始）の店舗への導入, の三点を重点的に進めていくこ とが発表された ${ }^{13)}$ 。中でも両者の特徵的な相互関係が見 られるのが,（1）と（2）である。元々スタバは，決済 に使用できるプリペイドカードである「スターバックス カード」（2002 年〜) を発行し，モバイル上での「モバ イルスターバックスカード」（2014 年〜）も提供してい た。LINE スターバックスカードはそれらと同様に, 現 金あるいはクレジットカード, LINE Pay などでチャージ することで店舗での支払に使え，スタバのポイント「Star」 を貯めることも，クーポンを入手することもできる（た だし，スタバの会員プログラム「My Starbucks」未加入 の場合は Starbucks eTicket を得ることはできない)。My Starbucks の既存会員は, LINE 側でカードを登録すると, それと既存のスターバックスカード情報とを紐付けるこ とができ, My Starbucks で両方のスターバックスカード にチャージ済みの残高を管理できる。

スタバは従来, Twitter や Facebook, Instagram といっ たSNS には公式アカウントを設置してきたが, LINE 公 式アカウントは期間限定での開設であった。スタバでは, 顧客との One to One コミュニケーションをより進めるた めに, 2019 年から LINE 公式アカウントを継続開設する こととし，今後も機能拡充を目指しているとされる。

\section{（3）スターバックスによる LINE 利用の選択と LINE に}

\section{よる機能の取り込み}

こうした動きの中に, LINE という PF に補完者として 参加したスタバが, 全ての顧客接点機能を LINEに依存 しているわけではないことが確認できる。例えば，ス夕 バの自社モバイルアプリでも LINE 公式アカウントでも, クーポンの入手や決済を行うことは可能である。「おすす めの商品」や「ギフトを贈る」などの機能は双方に備わっ ている。しかし一方で, 事前オーダーや,「Starbucks Rewards」で貯めたポイントを店舗で商品と交換可能な
「Starbucks eTicket」の入手には, スタバの自社モバイル アプリが必要となる。また, LINE 経由ではなく, 自社 アプリで入手できるクーポンには，ドリンクの有料カス 夕ムを無料にする「カスタマイズチケット」という有料 カスタムのトライを促す機能もあり, 表層的には同じクー ポン機能の中でも棲み分けを図っている14)。

プリペイドカード機能の提供 (スターバックスカード) がLINE スターバックスカードだけでなく，自社独自の プラスチックカードや自社アプリ機能によるプリペイド カードもあることに着目したい。スターバックスカード によるキャッシュレス決済は, 米国においては Apple Pay と同水準の普及率を持っていたこともある15)。こういっ た米国での高い普及率を背景として, スタバは, PF であ る LINE にプリペイド型の決済機能を全て委ねる気はな いものと考えられる。実際，同社は自社独自決済を行う 理由として，顧客データの直接取得をあげている 16)。同 様の理由から, ポイントサービスも PF が提供する共通 ポイントは導入していない。

一方で, LINEもまた, 補完者であるスタバに単に PF 機能を提供しているわけではない。LINE はまず，ス夕 バとの取り組みによって, LINE Payの利用促進をはか る。また，スタバの公式アカウントでは，LINE スター バックスカードでの購買データに基づくキャンペーンな どの告知やパーソナライズ化したメッセージの送信がな される。ここでLINE が独自に集客しているのは，ス夕 バの独自サービスである My Starbucks への登録にハード ルを感じる, あるいはその存在に気づいていなかったス タバのライトユーザーである。また, LINE 側としては, スタバのような, 幅広い顧客層に関するレコメンデーショ ン, 決済までの流れのデジタル化に取り組んでいる企業 と提携することで, 同種の業界・企業へと横展開可能な サービス開発へと結びつけ，事業拡大を図っていると考 えられる17)。

以上で見た通り, IO としてのスタバと, PF としての LINE は, 協業して相互に活動する一方で, それぞれ個 別に機能強化にも取り組んでいる。また, 協業の一方で, 顧客コミュニケーションや決済などの顧客接点をめぐっ ては一部競争関係にもあるため, お互いの機能をどう併 用させるかに関する駆け引きがなされているのである。 


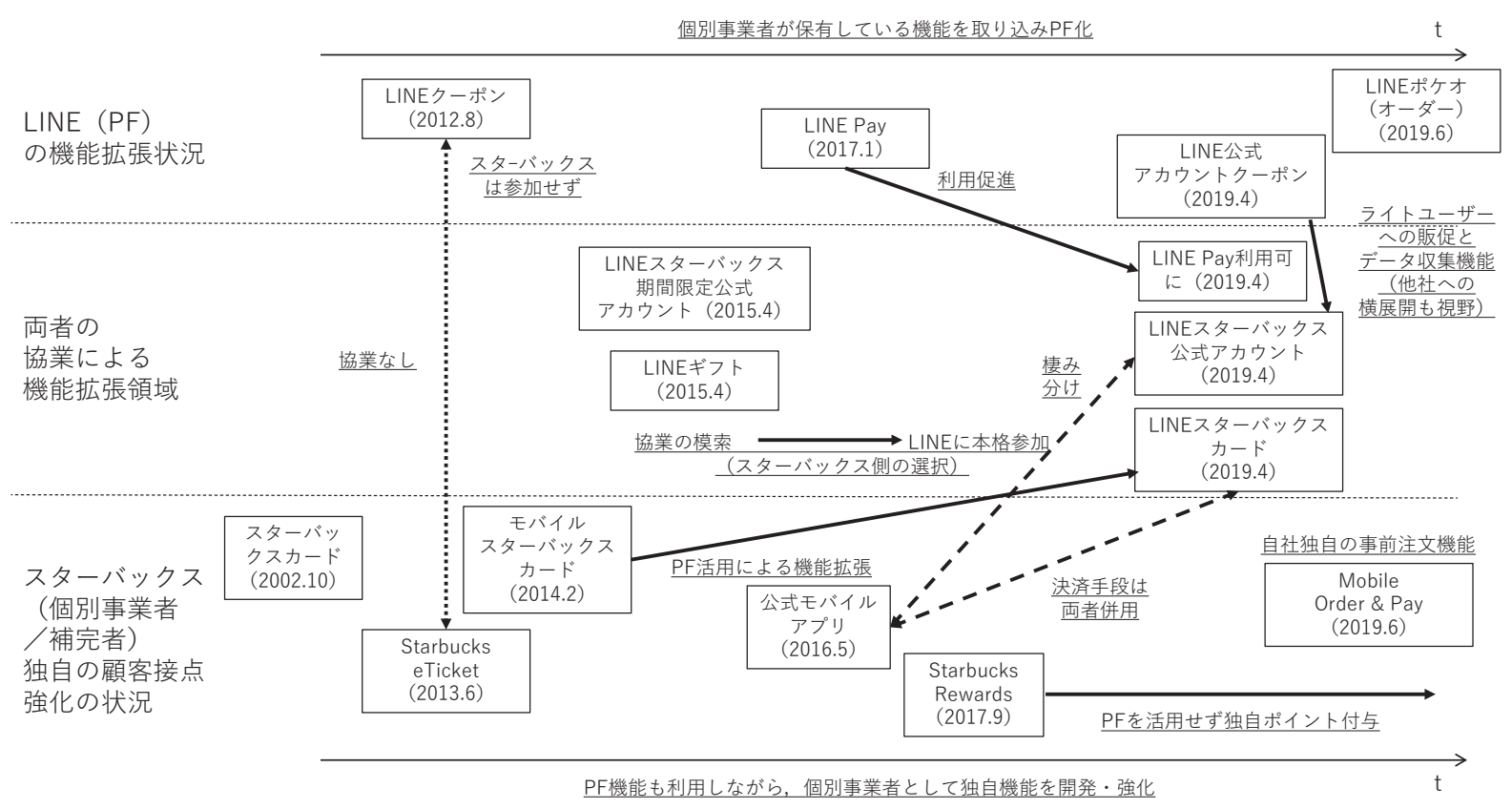

出典：筆者作成。

スタバと LINE の事例分析の要点を整理すると図 2 の 通りとなる。IO (補完者) であるス夕バは顧客接点を $\mathrm{PF}$ に奪われないために, PF の動きを参照しつつも, 独自に 機能強化を図っている。また, PF である LINE に参加す る際にも, 顧客接点機能を全て LINEに委ねる選択はし ていない。一方で, LINE はIO であるス夕バの提供機能 を取り込むことで，例えば LINE Pay の決済利用者や補 完者のライトユーザーへの販促や顧客情報収集などを強 化している。

\section{IV. ディスカッション}

\section{1. 事例分析の総括と解釈}

本稿の事例分析の主要な発見事実は以下の二点であ る。第一に, 飲食店業界の顧客接点機能をめぐって, 補 完者（個別事業者 $(\mathrm{IO})$ ) と PF の間に, どういう機能を 実装するかについての競争が存在している。そこでは, IO が機能毎に選択的に PF を活用しながら, あるいは相
互に機能発展を参照しながら, それぞれが顧客接点のた めの提供機能を発展させる取り組みが行われている。

第二に, PF と IO (補完者) の顧客接点機能の内容は, それぞれ力点が異なる。本稿では顧客接点機能強化の目 標を, 「潜在顧客へのリーチ拡大, 新規顧客獲得, 顧客維 持率向上, 利用頻度向上, 顧客単価向上」と考えている。 これらの目標は, 本稿事例では, 以下のように役割分担 されていると理解できる。

飲食店業界においては, PF は, 特に潜在顧客へのリー チ拡大, 新規顧客獲得のための取り組みに力点を置いて いると考えられる。これらは, PF としてのネットワーク 効果が発揮しやすい機能である。スタバと LINE との取 り組みで観察できるのは, LINE はス夕バに頻繁に通う 既存顧客ではなく，ライトユーザー（潜在顧客や新規顧 客）をターゲットにしていたということである。

一方で, IO が力を入れるのは, 既存顧客の顧客維持率 向上, 利用頻度向上, 顧客単価向上である。例えば, ス 夕バは,これらの目的のために, 既存顧客の利便性アッ プと個別の購買行動データ取得を意識して,「Starbucks 
Rewards , 「Mobile Order \& Pay」や独自の電子マネー決 済「スターバックスカード」を開発・実装している。

もっとも，上記の解釈は，PF あるいは IO（補完者で もある）が，新規顧客か既存顧客のいずれかにのみ注力 するということは意味しない。PF は, 顧客接点機能を, 個別事業者をまたがって共通化することで, 消費者と IO との間に入り, その利用率を高め, 結果として IO の PF 依存を高めようとする。しかし, IO も PF に顧客接点を すべて奪われまいと, 独自モバイルアプリなどで PF の 機能を自社に取り込み, 顧客接点機能を自社化すること で，消費者の直接的囲い达みを図ることがある。

\section{2. 媒介型 PF と個別事業者の相互作用的進化のモデル と一般化仮説}

本稿の RQ は，媒介型 PF と IO のマーケティング機能 (顧客接点機能) の相互作用的進化の具体的内容とそのメ カニズムを問うものである。事例分析と上述の解釈に基 づき, この相互作用的進化は以下の通りモデル化できる。 まず，媒介型 PF は，そもそも IO が保有していた顧客接 点に関連するマーケティング機能を取り込み, PF サービ スを IO に提供する。本稿では, III 章 1 節の「飲食店業 界におけるマクロ的観察」で確認したように, 媒介型 $\mathrm{PF}$ はIO をまたがる共通機能として提供できるサービスを 開発することでIO を取り込もうとする。

そして PF 機能がIO に対して提供されると, IO は自 社の広義の CRM 戦略に合致する $\mathrm{PF}$ 機能を選択し, それ に参加（利用）する。しかし, 一方で, IO は顧客接点を 全て PF に奪われないように，機能の自社化を図ったり， $\mathrm{PF}$ 機能と自社独自の顧客接点機能との棲み分けを図っ たりすることで, 顧客接点を奪い返そうとすることがあ る。一方 PF は, IO をまたがるネットワーク効果によっ て，また消費者の行動データを，IO をまたがって蓄積し て, IO の PFへの依存度を高めて囲い込みを図る。

このように, 媒介型 PF と IO の顧客接点機能は相互作 用的に進化していく。このメカニズムは, 図 3 の「媒介 型 PF と個別事業者の相互作用的進化のモデル」におい て, $\mathrm{PF}$ 機能をめぐる, $\mathrm{PF}$ 側の「機能を取り込み開発・ 提供」「共通化と消費者行動デー夕の蓄積で個別事業者を 囲い込み」, IO 側の「選択 - 参加」「PF 機能と自社機能
の棲み分け」「社内プロセス化 (実装)」として表現でき る。このメカニズムは, 上述の事例分析に基づいて, 以 下の一般化仮説として命題化できる。

仮説 1 : 媒介型プラットフォームと個別事業者のマーケ ティング機能（顧客接点機能）は, 相互的機能 拡張競争によって発展する。

仮説 1-1：媒介型プラットフォームは, 個別事業者の 顧客接点機能を取り込み, 個別事業者をま たがる共通化を行うことで発展する。

仮説 1-2：個別事業者は媒介型プラットフォームに機 能ごとに選択的に参加すると同時に, 顧客 接点を全てプラットフォームに奪われない ように，自社の社内プロセスとして独自機 能を開発・実装することがある。

図 3 の中央部分は, 本稿の事例に見られた, IO と媒介 型 PF の「協業的相互作用」である。協業の当事者であ る IO（例：スタバ）は, PF のネットワーク効果を活用 するために, PF との協業的機能開発に応じたり働きかけ ることがある。一方, PF は, 協業的に開発された PF 機 能を他の IO に横展開していくことによって PF 機能をさ らに進化させていく。例えば，LINEには，スタバとの 協業の成果を活かし, さらに機能追加したサービスとし て, 東急「どこ渋」モバイルオーダー（2021 年 1 月開 始）がある。このサービスでは，東急不動産のテナント である渋谷ヒカリエの店舗等を対象に, LINE から注文 と決済ができるだけでなく，クーポンを発行したり， LINE ミニアプリを会員証として活用したりすることで, 実店舗での購買結果を踏まえて, LINE 公式アカウント を通じて再購買を促進することなどができる。

この「協業的開発・横展開」メカニズムは, 以下のよ うに命題化できる。

仮説 2 : 個別事業者は媒介型プラットフォームのネット ワーク効果を活用するために，協業的にプラッ トフォーム機能の開発を行うことがある。プラッ トフォームは, そうして開発した新機能を他の 個別事業者・他業界に横展開する。 


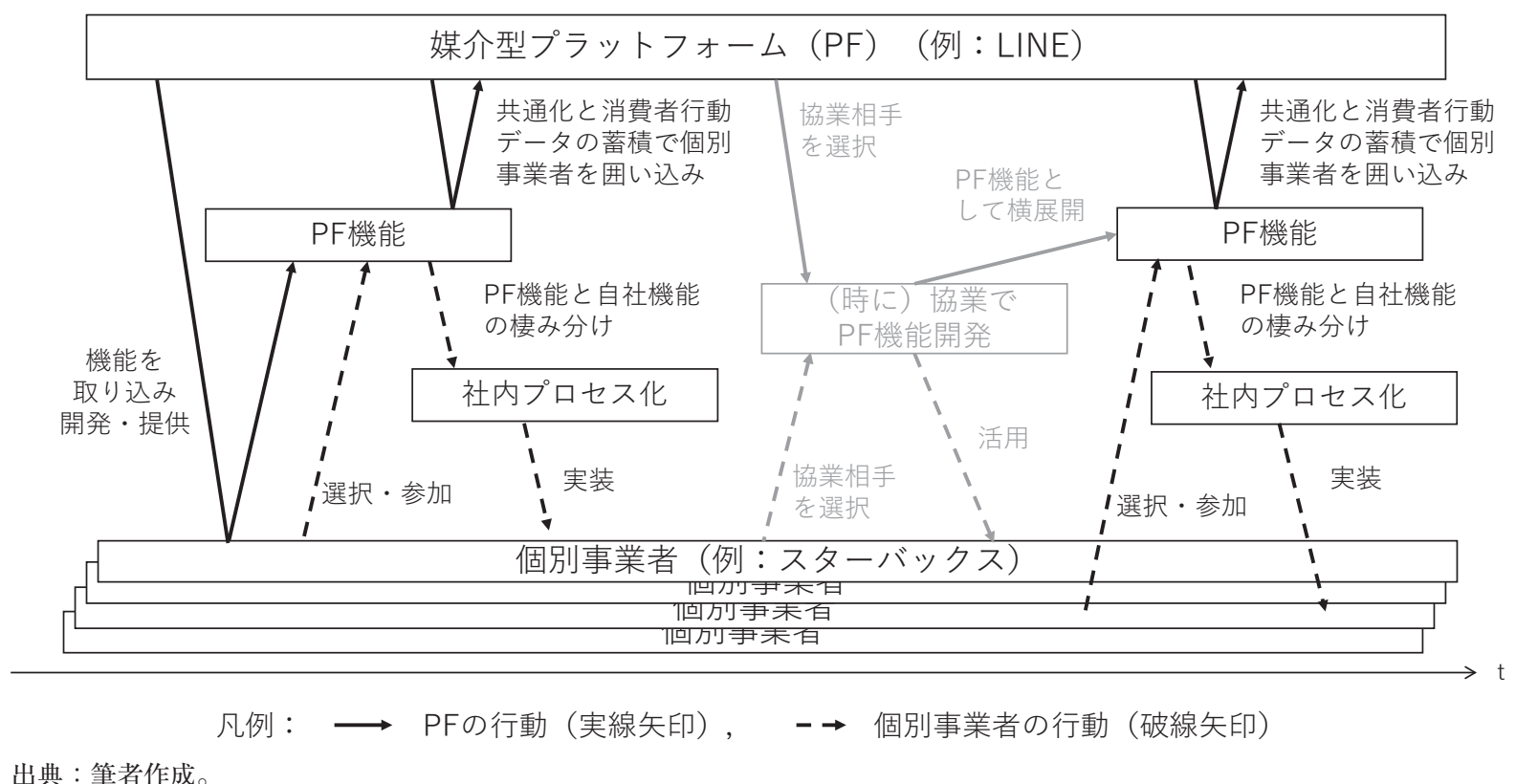

この相互作用は一度限りではなく, 何度も繰り返され るものと考えられる。

\section{V. 結語}

本稿で導出したモデルと仮説は，まずは事例分析の対 象である飲食店業界を前提とした $\mathrm{B} 2 \mathrm{C}$ ビジネスに扔ける 顧客接点を代替あるいは提供する媒介型 PF に関わるも のである。しかし，本モデルと仮説が一般化の範囲とし て想定しているのは，媒介型 PF の部分である「ネット 以前から存在していたIO のビジネス機能の一部を分離 して, 企業をまたがって横断的に提供する PF と IO の関 倸におけるマーケティング機能の相互的発展一般」であ る。例えば，本稿で提案したモデル・仮説は，小売業界 の決済・ポイント機能などを巡る，IO と媒介型 PF の相 互作用などにも適用できる可能性があるだろう。具体的 には，ファミリーマートの独自サービス「ファミペイ」 と T-POINTやd ポイントなどの PF との関係について, 本稿のモデル・仮説が当てはまると考えられる。
本稿の命題は, IO が PF に対抗するための実務的イン プリケーションを持つ。ただし, デジタルな手法で顧客 接点機能を内部化できるのは, 現状では一部の有力企業 （大規模チェーン）だけだろう。現状では, 広告, 決済, デリバリーといったプロセスに打りる PFへの依存は, 小規模な IO にとっては一方的に拡大している状況にあ る。また, 大規模チェーンを持つ IO が PF の持つ顧客接 点機能を自社プロセスに内部化したとしても, PF の有す るネットワーク効果やコスト優位と同等のものを築くの は難しいこともあり，すべての顧客接点で PF と同等な 力を持つことは困難である。ただし，有力な IO が機能 拡張をはかることは, PF の市場独占への一定の拮抗力に はなりえる。また, IO の機能拡張を助ける, バックヤー ド業者としてのシステム事業者の発展の動き（例：電子 マネーやデリバリー機能を自社アプリに組み込むための SaaS）は，独自機能を実装できる IO の範囲を拡大する だろう。さらに，実務的課題としては，IO が PF 機能と 自社機能を，どのような条件下で使い分けすべきかといっ た，PF 依存の選択基準問題なども解明する必要がある。 最後に本稿の学術的意義に関して再考しておきたい。 
本稿の RQ に対応するモデルと仮説は，マーケティング 機能, 特に顧客接点機能に関する媒介型 PF と IO の間の 相互発展の分析に留まっている。しかし，この研究の問 題意識は，学術的にはツーサイド $\mathrm{PF}$ 論を暗黙の前提に している既存研究と異なる理論的パースペクティブを示 すことであった。本稿で示唆した新しいパースペクティ ブは, PFを中心に据えた補完者の管理と補完者側からの 対応ではなく, PF と IO を対等の当事者として設定し て，両者の間でどのように相互作用的進化が起きている のかに着目するものである。本稿は，飲食店業界に関す る事例研究であったが, マーケティング機能に関する PF と IO の相互作用は, サービス業界や製造業等にも及ぶ と考えている。したがって, 問題意識の深化のために, まずマーケティング機能に関して，他業界の調査を通じ た仮説の確認や拡張が必要だと考えている。さらに, マー ケティング機能ほど顕著な現象ではないとはいえ，調達 や求人機能などの他機能にも同様な相互作用がありえる。

対象業界と着目機能の拡張によって，本稿が提示する 「PF と IO の相互作用的進化のパースペクティブ」を， プラットフォーム理論における新たな視角として確立し えると考えるものである。

\section{謝辞}

本研究は JSPS 科研費（基盤研究（B）19H01534，若 手研究 18K12867）からの支援を受けて行われました。

\section{注}

1）本稿での議論は，経営学における「共進化」論（Volberda \& Lewin, 2003）の一種ともいえる。ただし, 共進化論は, サプライチェーン上の取引企業間（例：部品企業と組み立 てメーカーの相互作用）や競合企業間（競争ダイナミクス (Chen \& Miller, 2012)）について主に議論されてきた歴史が あり, 本稿が取り上げる PF と IO の相互作用的進化を対象 にするものではない。本稿が分析の対象とする「顧客接点 の奪い合い」の時系列的発展は，媒介型 PF と IO の間に特 有のものであり, その点で従来の共進化に関する議論とは 異なる。

2）インタビューは，以下の 2 名の各企業のマーケティング部 門の幹部またはその経験者（匿名）に対して行った。(1) スターバックスコーヒージャパン株式会社 A 氏（2019 年 11 月 21 日), (2) 日本マクドナルド株式会社 B 氏（幹部経 験者）（2019 年 11 月 23 日）。

3) McDonald's Holdings Japan (n.d.)

4) LINE Corporation (2012)
5) MarkeZine editorial department (2018)

6) McDonald's Holdings Japan (2015)

7）日本マクドナルド株式会社 B 氏インタビューより。

8) Ryutsuu news (2017)

9）「スターバックスが提供するシームレスな“感動体験”」（ス ターバックス コーヒージャパン CRM 部長 清水省吾氏 講演（2020年 1 月 28 日，マーケティング・テクノロジー フェア東京 2020) )

Starbucks Coffee Japan (2017)

10) Starbucks Coffee Japan（2019）

11）スターバックスコーヒージャパン株式会社 A 氏インタ ビューより。

12）注 11 に同じ。

13) Starbucks Coffee Japan (2018) Inoue and ITmedia (2019)

14）注 11 に同じ。

15) Takahashi (2018)

16) 注 11 に同じ。

17) Kobayashi (2019)

\section{References}

Armstrong, M. (2006). Competition in two-sided markets. The RAND Journal of Economics, 37(3), 668-691. doi: j. 1756-2171.2006.tb00037.x

Boudreau, K. (2010). Open platform strategies and innovation: Granting access vs. devolving control. Management Science, 56(10), 1849-1872. doi: 10.1287/mnsc. 1100.1215

Ceccagnoli, M., Forman, C., Huang, P., \& Wu, D. J. (2012). Cocreation of value in a platform ecosystem: The case of Enterprise Software. MIS Quarterly, 36(1), 263-290. doi/ $10.5555 / 2208955.2208971$

Cennamo, C., \& Santalo, J. (2013). Platform competition: Strategic trade-offs in platform markets. Strategic Management Journal, 34(11), 1331-1350. doi: 10.1002/smj.2066

Chen, M. J., \& Miller, D. (2012). Competitive dynamics: Themes, trends, and a prospective research platform. Academy of Management Annals, 6(1), 135 - 210. doi: 10.5465/ 19416520.2012 .660762

Cusumano, M. A., Gawer, A., \& Yoffie, D. B. (2019). The business of platforms: Strategy in the age of digital competition, innovation, and power. New York: Harper Business.

Edelman, B. (2014). Mastering the intermediaries. Harvard Business Review, 92(6), 86-92.

Eisenhardt, K. M. (1989). Building theories from case study research. Academy of Management Review, 14(4), 532-550. doi: $10.2307 / 258557$

Eisenmann, T., Parker, G., \& Van Alstyne, M. W. (2006). Strategies for two-sided markets. Harvard Business Review, 84(10), 92101.

Eisenmann, T., Parker, G., \& Van Alstyne, M. W. (2011). Platform envelopment. Strategic Management Journal, 32(12), 12701285. doi: $10.1002 /$ smj. 935

Gawer, A. (2009). Platform dynamics and strategies: From products to services. In A. Gawer (Ed.). Platforms, Markets 
and Innovation (pp. 45-76). Cheltenham: Edward Elgar Publishing.

Hagiu, A., \& Yoffie, D. B. (2009). What's your Google strategy? Harvard Business Review, 87(4), 74-81.

Inoue, S., \& ITmedia. (2019). Sutaba to LINE no houkatsuteikei start LINE apuri kara "Starbucks card" hakkou kanouni. ITmedia. Retrieved from https://www.itmedia.co.jp/mobile/ articles/1904/08/news113.html (May 23, 2021). (井上翔・ ITmedia（2019）。「スタバと LINE の包括提携スタート LINE アプリから「スターバックスカード」発行可能に」 『ITmedia』) (In Japanese)

Kobayashi, Y. (2019). Starbucks to LINE no teikei service ga start. BUSINESS INSIDER JAPAN. Retrieved from https:// www.businessinsider.jp/post-188753 (May 23, 2021). (小林優 多郎（2019）。「スターバックスと LINE の提携サービスが スタート」『BUSINESS INSIDER JAPAN』）(In Japanese)

LINE Corporation. (2012). "LINE coupon" ga open. LINE Corporation. Retrieved from https://official-blog-ja.line.me/ archives/14961492.html (May 23, 2021). (LINE 株式会社 (2012).「「LINE クーポン」がオープン」『LINE 株式会社』) (In Japanese)

MarkeZine editorial department. (2018). SmartNews, zenkoku nimanten no coupon jouhou wo haishin suru "coupon channel" wo release. MarkeZine. Retrieved from https://markezine.jp/ article/detail/28003 (May 23, 2021). (マーケジン (2018).「ス マートニュース，全国 2 万店のクーポン情報を配信する 「クーポンチャンネル」をリリース」『MarkeZine』) (In Japanese)

McDonald's Holdings Japan. (2015). Smartphone muke "McDonald's koushiki apuri" wo sasshin. McDonald's Holdings Japan. Retrieved from https://www.mcd-holdings.co.jp/news/2015/ promotion/promo0508a.html (May 23, 2021).（日本マクドナ ルドホールデイングス株式会社（2015）。「スマートフォン 向け「マクドナルド公式アプリ」を刷新」『日本マクドナル ドホールディングス株式会社』）(In Japanese)

McDonald's Holdings Japan. (n.d.). History. McDonald's Holdings Japan. Retrieved from https://www.mcd-holdings.co.jp/ company/history/ (May 23, 2021).（日本マクドナルドホール ディングス株式会社（n.d.）。「沿革・歴史」『日本マクドナ ルドホールディングス株式会社』）(In Japanese)

McIntyre, D. P., \& Srinivasan, A. (2017). Networks, platforms, and strategy: Emerging views and next steps. Strategic Management Journal, 38(1), 141-160. doi: 10.1002/smj.2596

Moazed, A., \& Johnson, N. L. (2016). Modern monopolies: What it takes to dominate the 21st century economy. New York: St. Martin's Publishing Group.

Negoro, T. (2017). Platform no kyoukasyo. Tokyo: Nikkei Business Publications. (根来龍之 (2017).『プラットフォームの教科 書』日経 BP) (In Japanese)

Negoro, T., \& Ajiro, S. (2013). An outlook of platform theory research in business studies. Waseda Business \& Economic Studies, (48), 1-29.

Parker, G., Van Alstyne, M. W., \& Choudary, P. C. (2016). Platform revolution: How networked markets are transforming the economy - and how to make them work for you. New York: W. W. Norton \& Company.

Ryutsuu news. (2017). Starbucks / hatsu no point service "Starbucks Rewards" kaishi. Ryutsun news. Retrieved from https://www.ryutsuu.biz/strategy/j091910.html (May 23, 2021).（流通ニュース (2017).「スターバックス/初のポイ ントサービス「スターバックスリワーズ」開始」『流通 ニュース』) (In Japanese)

Shibuya, S. (2009). Marketing kenkyuu ni okeru case study no houhouron. In K. Kawamata, T. Yoda, \& K. Kuroiwa (Eds.). Marketing kagaku no houhouron (pp. 111-139). Tokyo: Hakuto-Shobo Publishing.（澁谷覚（2009）。「マーケティン グ研究におけるケース・スタディの方法論」川又啓子・余 田拓郎・黒岩健一郎（編）『マーケティング科学の方法論』 pp. 111-139，白桃書房）(In Japanese)

Starbucks Coffee Japan. (2017). Okyakusama no taiken wo yori yutaka ni suru hatsuno loyalty program "STARBUCKS REWARDS"TM" kugatsu nijuunichi kara teikyou wo kaishi. Starbucks Coffee Japan. Retrieved from https://www.starbucks.co.jp/ press_release/pr2017-2631.php?nid=nw_01_pc (May 23, 2021). (スターバックスコーヒージャパン (2017)。「打客 様の体験をより豊かにする初のロイヤルティ プログラム 「STARBUCKS REWARDS ${ }^{\mathrm{TM}}$ (スターバックスリワー ドTM)」9 月 20 日から提供を開始」『スターバックスコー ヒージャパン』）(In Japanese)

Starbucks Coffee Japan. (2018). LINE kabushikigaisha to Starbucks Coffee Japan kabushikigaisha ni yoru houkatsuteki na gyoumuteikei teiketsu ni tsuite. Starbucks Coffee Japan. Retrieved from https://www.starbucks.co.jp/press release/ pr2019-2834.php (May 23, 2021). (スターバックス コーヒー ジャパン（2018）。「LINE 株式会社とスターバックスコー ヒージャパン株式会社による包括的な業務提携締結につい て」『スターバックスコーヒージャパン』) (In Japanese)

Starbucks Coffee Japan. (2019). Kakushinteki de seamless na digital taiken wo Starbucks to LINE de jitsugen. Starbucks Coffee Japan. Retrieved from https://www.starbucks.co.jp/ press_release/pr2019-3007.php (May 23, 2021). (スターバッ クスコーヒージャパン (2019).「革新的でシームレスなデ ジタル体験をスターバックスと LINE で実現」『スターバッ クスコーヒージャパン』）(In Japanese)

Takahashi, N. (2018). Starbucks no mobile shiharai service, Apple Pay wo bisa de lead (beikokunai). TechCrunch Japan. Retrieved from https://jp.techcrunch.com/2018/05/23/ 2018-05-22-starbuckss-mobile-payment-service-is-slightlyoutpacing-apples/ (May 23, 2021). (高橋信夫 (2018). 「スター バックスのモバイル支払いサービス, Apple Pay を微差で リード（米国内）」『TechCrunch Japan』）(In Japanese)

Volberda, H. W., \& Lewin, A. Y. (2003). Co - evolutionary dynamics within and between firms: From evolution to co - evolution. Journal of Management Studies, 40(8), 2111-2136. doi: 10.1046/j.1467-6486.2003.00414

Wang, R. D., \& Miller, C. D. (2020). Complementors' engagement in an ecosystem: A study of publishers' e-Book offerings on Amazon Kindle. Strategic Management Journal, 41(1), 3-26. 
Special Issue 特集論文

doi: 10.1002/smj.3076

Yin, R. K. (1994). Case study research: Design and methods (2nd ed.). New York: Sage Publications.

\section{根来 龍之（ねごろたつゆき）}

早稲田大学大学院経営管理研究科 (ビジネススクール) 教授 京都大学文学部卒業。慶應義塾大学大学院経営管理研究科 （MBA）修了。鉄鋼メーカー，文教大学などを経て，現職。 英ハル大学客員研究員, 米カリフォルニア大学客員研究員, 経営情報学会会長などを歴任。専門は, プラットフォーム 戦略論,ビジネスモデル論,デジタル戦略。

\section{足代 訓史（あじろさとし）}

拓殖大学商学部准教授

早稲田大学商学部卒業。早稲田大学大学院商学研究科博士 後期課程単位取得満期退学。株式会社日本総合研究所研究 員, 早稲田大学商学学術院助教, ブリティッシュコロンビ ア大学客員准教授などを経て, 現職。専門は, 競争戦略と イノベーション, アントレプレナーシップ。 